\title{
Construction of KPI-based motivation policy for advancing sustainable procurement logistics of agricultural enterprises: competence approach
}

\author{
Lyubov Lipych* \\ Oksana Zelenko** \\ Sergeii Zelenko*** \\ Myroslava Kushnir ${ }^{* * *}$ \\ Oksana Khilukha****
}

Received: 2021-02-17

Accepted: 2021-04-21

DOI: http:/ / doi.org/ 10.46489/lbsh.2021-1-1-1

\begin{abstract}
In challenging economic conditions, motivational mechanisms capable of maintaining sustainable logistics management of agricultural enterprises are declining. This study aims to specify the forms of connecting the motivational policy, KPI and sustainable logistics of agricultural enterprises. As a result of theoretical research, we have proved that the competencies of logistics managers can be the appropriate connector. We have considered the hypothesis that there are key competencies that logistics managers recognize as the most important and most often implemented for advancing sustainable procurement logistics. To confirm the hypothesis, we collected data from interviews with logistics managers of Ukrainian agricultural enterprises. To process the data, we used the method of integrated $\mathrm{ABC}-\mathrm{XYZ}$ analysis. As a result, we found that the $\mathrm{AX}$ group (the most important and frequently used competencies) includes the high general qualification and the ability to assess the effectiveness of logistics operations and processes objectively. Unlike other studies, the novelty of the presented results is as follows. We advocate the idea of the motivational influence of performance indicators and propose to form KPI system taking into account the importance and frequency of using the established competencies of logistics managers. Our proposals are a prerequisite for developing a flexible motivational policy for sustainable procurement logistics.
\end{abstract}

Keywords: sustainable development goals, logistics system of the enterprise, logistics management, motivational strategy, key performance indicators, key competencies of managers

\footnotetext{
* Lyubov Lipych, DSc (Economics), Professor, Department of Entrepreneurship, Trade and Logistics, Lutsk National Technical University, Lvivska 75, Lutsk, Ukraine, e-mail: lglipych@gmail.com, ORCID: https://orcid.org/0000-0002-9059$\underline{7271}$ (corresponding author)

** Oksana Zelenko, PhD, assistant, Department of Management, Lutsk National Technical University, Lvivska 75, Lutsk, Ukraine, ORCID: https://orcid.org/0000-0002-9004-0203

*** Sergeii Zelenko, PhD, Associate Professor, Department of Accounting and Auditing, Lutsk National Technical University, Lvivska 75, Lutsk, Ukraine, ORCID: https://orcid.org/0000-0001-6074-1749

**** Myroslava Kushnir, PhD, Art. teacher, Department of Applied Economics and Business, Ukrainian Catholic University, Ilariona Sventsitskoho 17, Lviv, Ukraine, ORCID: https://orcid.org/0000-0002-4441-4278

${ }^{* * * * *}$ Oksana Khilukha, PhD, Associate Professor, Department of Enterprise Economics and Information Technology, Lviv University of Business and Law, Kulparkivska 99, Lviv, Ukraine, ORCID https://orcid.org/0000-0002-1228-7171
} 


\section{INTRODUCTION}

The agricultural sector plays an essential role in the economy of Ukraine, providing 9\% of GDP, $18 \%$ of employment and $6 \%$ of tax revenues. The dynamic development of the national agro-industrial complex ensures the competitiveness of Ukraine's economy. It is also a tool for Ukraine to enter the export markets of other countries and take a leading position in the most substantial suppliers of agricultural products. Already, Ukraine is in the top 3 most noticeable suppliers of agricultural products in the EU and occupies a significant place in world trade (Dankevych, E., Dankevych, V., \& Chaikin, O., 2017).

Competitive advantages of agricultural organizations depend not only on the available material resources and the level of their use. Intangible factors play a crucial role, the most important of which is management. The effectiveness of management in a competitive environment depends on the timely implementation of new approaches to respond quickly to new challenges (Anokhina, M. Y. et al., 2020). Beside this, we should take into account sustainability issues.

Agro-industrial enterprises play a significant role in achieving the goals of sustainable development in Ukraine. In previous studies, the authors have shown their involvement in reducing rural poverty (goal 1) (Gaspart, 2013), achieving food security (goal 2) (Dar, \& Laxmipathi Gowda, 2013), and ensuring responsible production (goal 12) (Cavalett et al., 2016). In the internal organizational dimension, agro-industrial enterprises aim to participate in sustainable economic growth (goal 8) (Ciglovska, 2018).

The first stage of production in agricultural enterprises is procurement. Production, financial, sales and organizational activities directly depend on its condition (Volkonskaya, 2020). We can interpret material (raw materials, capital, capital) and human (labour and entrepreneurial skills) resources as a system in this process (Dubrovsky, 2004). In this system the following processes take place:

- acquisition, storage, provision of production with raw materials, auxiliary materials and production equipment, spare parts and materials for maintenance and repair of equipment;

- marketing activities related to procurement and supply processes;

- ensuring the economical turnover of agricultural products.

The latter process demonstrates the entry of material flow into the logistics system (Milan et al., 2018).

The task of procurement logistics is to effectively manage material flows to provide the company with material resources and satisfaction of production needs in materials with maximum economic efficiency (Kaur \& Singh, 2019). In this context, its goal is to minimize total costs. Such costs include those arising in the process of moving goods and services (products, raw materials, materials) from the sphere of production (from places of creation, extraction) to the sphere of consumption (including final and intermediate, as well as production-consumption) (Gayfullina \& Nizamova, 2020).

Effective management and timely use of logistics tools in the activities of agricultural enterprises demonstrates several advantages. It becomes possible to timely determine the needs of the enterprise in fixed assets, accurate assessment of the optimal areas of their use and maintenance and repair of agricultural machinery, equipment, buildings and more.

Logistics managers work to achieve the relevant goals. Thus, we assume that the possibility of advancing sustainable procurement logistics of agricultural enterprises depends on the quality of motivational policy. This policy should fully ensure the development of competence and engagement of managers.

\section{1. Literature Review}

In recent years, we have seen an increase in the number of studies on sustainable logistics. Soysal, M., \& Bloemhof-Ruwaard, J. M. (2017) investigated the evolution of the concept of sustainable logistics management. They proved that there is a high demand for more effective ways of providing environmental and social responsibility. Abbasi, M., \& Nilsson, F. (2016) described the challenges logistics management faces in achieving sustainability. Researchers 
attributed these challenges to consumer preferences, management difficulties, network imbalances, and technological and legal uncertainties.

Wichaisri, S., \& Sopadang, A. (2013) revealed the content of a sustainable logistics system that includes economic, social and environmental components. Sandberg, E., \& Abrahamsson, M. (2011) described in detail the potential of logistics to obtain sustainable competitive advantages. They concluded that managers should develop managerial knowledge, cross-functional teamwork, control, training, and supply chain relationships to support this capacity.

In the main activity of agricultural enterprises, it is possible to apply the methods of in-house logistics (Grabara, J., C. Dima, I., Kot, S., \& Kwiatkowska, J. (2011). Such instruments can help solve the problems of optimising the size of enterprises, determining the need for fixed assets, organisation of their productive use, and even human resources management. Björklund, M., \& Forslund, H. (2018), in the study of sustainable logistics, emphasised the importance of using logistics and customer KPIs, which opens opportunities for building a KPI-based motivation policy for advancing sustainable procurement logistics of agricultural enterprises.

\section{2. Theoretical basics of KPI-based motivation policy construction}

In preparing this study, we proceeded from the assumption that advancing sustainable procurement logistics of agricultural enterprises should be grounded on a KPI-based motivation policy.

The activity of any agricultural enterprise is mainly cyclical. We recognise logistics management as a management cycle that can be studied using the structural, process and functional approaches (Grabara, 2013).

As for an open system, the theoretical foundation of logistics is the general theory of systems and its tools: systems approach and analysis. The systems approach is a comprehensive study of the object as a whole from the standpoint of systems analysis
(Dubrovsky, 2004). Based on the findings of de Bruijn H., ten Heuvelhof E.F., \& in 't Veld R. (2010), we suppose that the process approach is crucial in the study of logistics operations and functions and related logistics costs. Also, we can use a functional approach to examine the management of individual objects, which are the parts of logistics operations and affects the formation of logistics costs (Somov, D., 2018).

For efficiency of procurement management, three goals are the core: faster, better, cheaper. Taking into account scarce resources, only two of these goals are reachable. Based on this assumption, we see the point in talking about the separation of two crucial criteria (for example, "cheaper" and "better", or "cheaper" and "faster"). It leads us to the admission of KPI system necessity. Its primary purpose is to measure and track the productivity of logistics processes. Besides this, KPI systems have proved their efficiency as a motivational instrument (Hall, D., R. Huscroft, J., T. Hazen, B., \& B. Hanna, J. (2013).

A well-developed KRI system is a basis for a correct assessment of the effectiveness of logistics process management in agricultural enterprises, namely in the sphere of procurement logistics (Sergeeva, 2019).

The primary purpose of using a KPI system in procurement logistics is to monitor, control and evaluate the efficiency of the logistics system as a whole (Guo, X., Chen, T., Chen, K., \& Tang, Y. 2020). Assessing the effectiveness of procurement logistics can bring light to the competitive advantages and bottlenecks of management. The importance of a high-quality evaluation process is unambiguous to stakeholders (Wannes, A., \& Ghannouchi, S. A. 2019), in particular, to the in-house logistics staff.

Depending on the situation, managers can ground on various principles to form a KPI system. As for our research, a possible approach is to classify the elements of the KPI system by defining principle criteria (Hamann, P. M., Schiemann, F., Bellora, L., \& Guenther, T. W., 2013) like effectiveness, efficiency, equity and economy (Davis, P. et al., 2013) (Figure 1). 


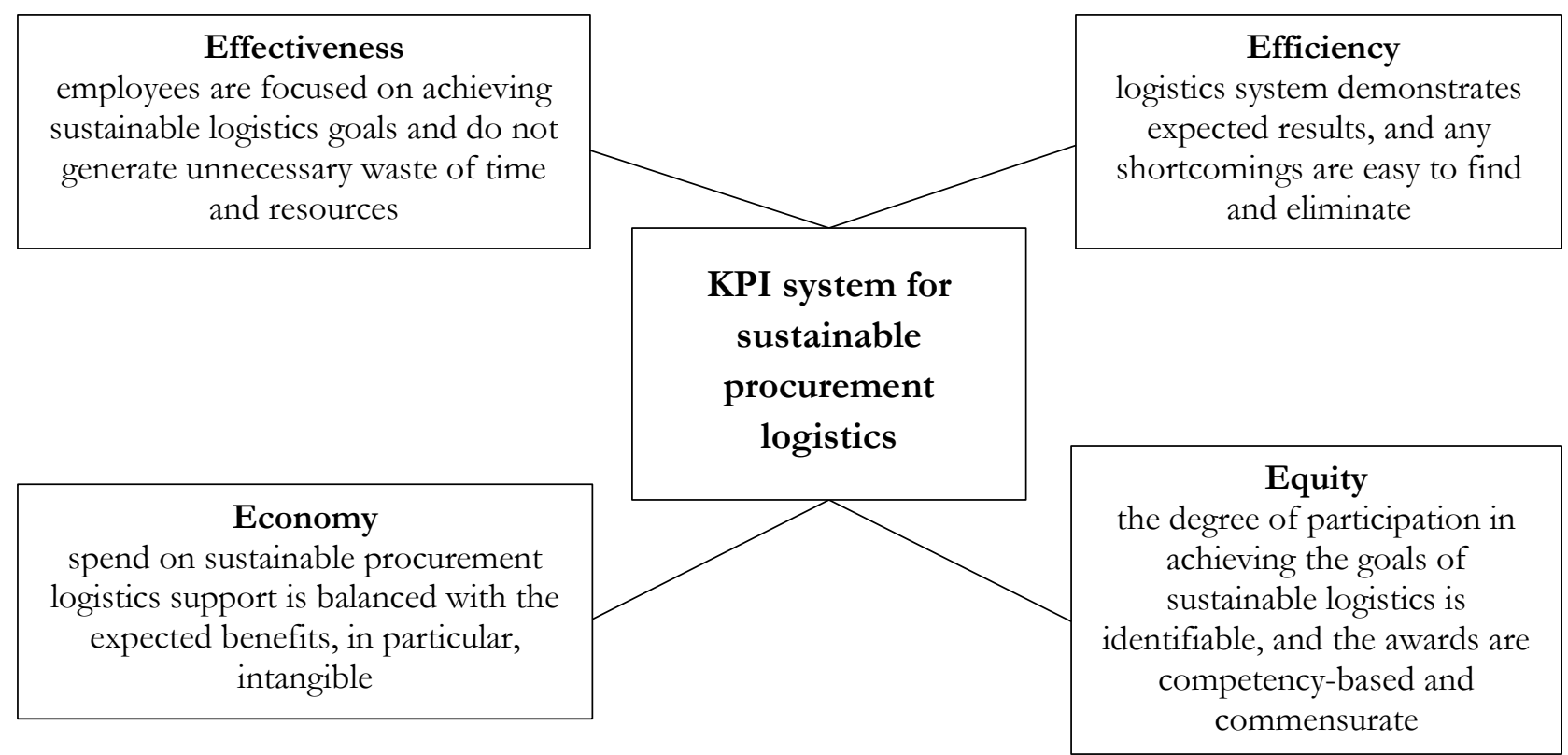

Figure 1. Schema of principles for the development of KPI system for sustainable procurement logistics

*Source: Wannes, A., \& Ghannouchi, S. A. 2019; Hamann, P. M., Schiemann, F., Bellora, L., \& Guenther, T. W., 2013; Davis, P. et al., 2013.

To gain motivational value, the evaluation of KPI should include four stages: internal evaluation, external expert evaluation; benchmarking; assessment of compliance with industry standards (Wang, Y., \& Hao, Y. (2013).

Our personal experience in the agricultural sector and communication with logistics managers shows the following. In Ukrainian agricultural enterprises, the KPI system usually corresponds to the principle of "pyramid". The "top" - is the enterprise's mission, which in terms of cost optimisation means achieving the maximum level of profitability. For logistics managers, their "top" is often the percentage of logistics costs in the price of goods. This approach is fragmentary and cannot demonstrate sustainability in logistics, so it is inefficient to develop a motivational policy. Achieving efficiency, integrity, and sustainability of procurement logistics depends on the KPI system designed to consider the hierarchy of crucial competencies of managers studied, particularly by Bahua M.I. (2018).

The logistics of Ukrainian agricultural enterprises are rather complex and not efficient enough. At the studied enterprises, the sphere of logistics management includes promotion, manipulation, storage, transportation and maintenance of stocks. According to managers, most enterprises urgently require reforms in their motivational strategy to promote sustainable logistics management. Therefore, there is a need to improve the motivational policy in the field of procurement. One way to achieve this goal is to implement a controlling system based on a structured KPI list (Guo, X., Chen, T., Chen, K., \& Tang, Y. 2020). For sufficient efficiency, this process, as dependent on the human factor, should be accompanied by a revision of the motivational component (Grabara, J., Cehlar, M., \& Dabylova, M. 2019).

Based on a review of sources and theoretical analysis, we formulated the following research question.

$\mathrm{RQ}_{1}$. What key competencies should we consider most important for constructing the KPI-based motivation policy for advancing sustainable procurement logistics of agricultural enterprises?

To answer this question, we must confirm the following hypothesis.

$\mathrm{H}_{1}$. There are key competencies that logistics managers recognise as the most important and frequently used for advancing sustainable procurement.

\section{METHODS}

Recent research on sustainable logistics management shows a high level of integrity and accumulation of applied experience (Grabara, 
2013). However, currently, there are no empirical studies based on which it would be possible to confirm our hypothesis.

We found the hypothesis confirmation scheme by analysing some of the data we collected during the previous study of agricultural enterprises' sustainable logistics. We obtained the initial data by conducting a series of interviews with logistics managers of Ukrainian agricultural enterprises in 2016-2019. These data, in particular, contained answers to the following questions: "Which of the competencies do you consider the most important for advancing sustainable procurement?" and "Which of the competencies do you use most often for advancing sustainable procurement?". Due to the limitations of the previous study model, we excluded these data. We decided to use them in a separate original study related to constructing a KPI-based motivation policy for advancing sustainable procurement logistics of agricultural enterprises.

We interviewed 65 logistics managers. All respondents gave their explicit consent to the use of survey data for research purposes based on confidentiality.

After studying the scientific sources, we identified the key logistics managers competencies, which significantly affect the achievement of KRI and are easy to recognise in agricultural enterprises procurement activities (Grabara, J., C. Dima, I., Kot, S., \& Kwiatkowska, J., 2011; Sandberg, E., \& Abrahamsson, M., 2011). The importance of these competencies coheres with the results of subsequent studies (Björklund, M., \& Forslund, H., 2018; Dankevych, E., Dankevych, V., \& Chaikin, O., 2017; Gayfullina, M.M., \& Nizamova, G.Z., 2020; Kaur, H., \& Singh, S.P., 2019).

Such competencies include high qualification (mastery in theory and practical tools of logistics) and abilities to:

- understanding the specifics of the industry and region;

- understanding the characteristics of the enterprise;

- analyse and forecast stocks and needs in them;
- react quickly to changes in the market these conditions;

- establish business relationships;

- analyse the structure of logistics costs and optimise it;

- assess the effectiveness of logistics operations and processes objectively;

- develop, improve, and implement new systems to optimise the logistics department's work;

- generate reports on logistics costs (in terms of month, quarter, year);

- coordinate document flow of logistics processes;

- the rational management of financial flows for the implementation of logistics operations.

We processed the data using the method of integrated ABC-XYZ analysis (Bulinski, J., Waszkiewicz, C., \& Buraczewski, P., 2013). We coded the interview data and performed a study in three stages.

At the first stage, we grouped key competencies into three groups: "A", "B", and "C". To do this, we calculated the share of respondents who acknowledged the importance of a particular competence. Then we sorted the competencies by weight and calculated the accumulated share. We calculated the accumulated share of positions for each of the competencies and got the value of the $\mathrm{IND}_{\mathrm{abc}}$ indicator. This indicator represents the ratio of the accumulated amount of the share to the accumulated share of positions. For group "A" items $\mathrm{IND}_{\mathrm{abc}}$ is from 3,077 to 3,508 (accumulated amount of share is nearly $80 \%$ ), in group "B" - from 1,272 to 2,400 (nearly $15 \%$ ), in group "C" - from 1,000 to 1,163 (nearly $5 \%$ ).

In the second stage, we performed an XYZ analysis. To do this, we calculated the average frequency of competencies uses. Respondents rated the frequency on a scale from 1 to 3, where 1 - daily, 2 - monthly, 3 quarterly. The concordance coefficient was $\mathrm{W}$ $=0.753$. The value of $\chi^{2}=54,216$ is greater than the tabular value $\left(\chi_{0,01(2)}^{2}=9,210\right)$. The most frequently used competencies were assigned to group $\mathrm{X}$, the rest to $\mathrm{Y}$ and $\mathrm{Z}$. 
In the end, we formed an integrated ABC-XYZ matrix of the logistics managers' competencies.

\section{RESULTS}

At the first stage of the study, we obtained the following results of the $\mathrm{ABC}$ analysis (Table 1).
The most important for sustainable procurement logistics are such competencies as high qualification (1), the ability to assess the effectiveness of logistics operations and processes objectively (2), The ability to analyse the structure of logistics costs and optimise it (3). We included these three competencies in group "A".

Table 1. ABC analysis of the logistics managers' competencies

\begin{tabular}{|c|c|c|c|c|c|c|}
\hline Competencies sorted by weight & $\begin{array}{l}\text { Share of } \\
\text { respondents } \\
, \%\end{array}$ & $\begin{array}{l}\text { Accumulated } \\
\text { amount of the } \\
\text { share, } \%\end{array}$ & $\begin{array}{l}\text { Share by } \\
\text { number, } \\
\%\end{array}$ & $\begin{array}{l}\text { Accumulated } \\
\text { share of } \\
\text { positions, } \%\end{array}$ & $\begin{array}{c}\mathrm{IND}_{\mathrm{ab}} \\
\mathrm{c}\end{array}$ & $\begin{array}{c}\text { Grou } \\
\mathrm{p}\end{array}$ \\
\hline $\begin{array}{l}\text { High qualification (mastery in theory and } \\
\text { practical tools of logistics) }\end{array}$ & 29,231 & 29,231 & 8,333 & 8,333 & 3,508 & \multirow{3}{*}{ A } \\
\hline $\begin{array}{l}\text { The ability to ability to assess the } \\
\text { effectiveness of logistics operations and } \\
\text { processes objectively }\end{array}$ & 26,154 & 55,385 & 8,333 & 16,667 & 3,323 & \\
\hline $\begin{array}{l}\text { The ability to analyse the structure of } \\
\text { logistics costs and optimise it }\end{array}$ & 21,538 & $76,923 \%$ & 8,333 & 25,000 & 3,077 & \\
\hline $\begin{array}{l}\text { The ability to develop, improve, and } \\
\text { implement new systems to optimise the } \\
\text { logistics department's work; }\end{array}$ & 3,077 & $80,00 \%$ & 8,333 & 33,333 & 2,400 & \multirow{6}{*}{ B } \\
\hline $\begin{array}{l}\text { The ability to analyse and forecast stocks } \\
\text { and needs in them }\end{array}$ & 3,077 & 83,077 & 8,333 & 41,667 & 1,994 & \\
\hline $\begin{array}{l}\text { The rational management of financial } \\
\text { flows for the logistics operations } \\
\text { realisation }\end{array}$ & 3,077 & 86,154 & 8,333 & 50,000 & 1,723 & \\
\hline $\begin{array}{l}\text { The ability to generate reports on } \\
\text { logistics costs (in terms of month, } \\
\text { quarter, year) }\end{array}$ & 3,077 & 89,231 & 8,333 & 58,333 & 1,530 & \\
\hline $\begin{array}{l}\text { The ability to establish business } \\
\text { relationships }\end{array}$ & 3,077 & 92,308 & 8,333 & 66,667 & 1,385 & \\
\hline $\begin{array}{l}\text { The ability to react quickly to changes in } \\
\text { the market conditions }\end{array}$ & 3,077 & 95,385 & 8,333 & 75,000 & 1,272 & \\
\hline $\begin{array}{l}\text { The ability to coordinate document flow } \\
\text { of logistics processes }\end{array}$ & 1,538 & $96,923 \%$ & $8,333 \%$ & $83,333 \%$ & 1,163 & \multirow{3}{*}{$\mathrm{C}$} \\
\hline $\begin{array}{l}\text { Understanding the specifics of the } \\
\text { industry and region }\end{array}$ & 1,538 & $98,462 \%$ & $8,333 \%$ & $91,667 \%$ & 1,074 & \\
\hline $\begin{array}{l}\text { Understanding the characteristics of the } \\
\text { enterprise }\end{array}$ & 1,538 & $100,000 \%$ & $8,333 \%$ & $100,000 \%$ & 1,000 & \\
\hline Total & 100,00 & - & 100,00 & - & - & - \\
\hline
\end{tabular}

Source: Own research

During the interview, some managers commented on these competencies as follows:

(1) "Of course, the skill of sustainable procurement logistics comes with experience. But in our team, it is considered a bad tone to "gain knowledge on the fly". The specialist must have the basic skills" (Mykhailo, 44).

(1) "Qualification of a manager is his main resource. We cannot admit unskilled workers to the procurement logistics processes" (Ivanna, 38).

(1) "We are proud of the principle of sustainability, which we practice in procurement logistics.
The implementation of this principle grounds on involving the managers who have the appropriate qualifications" (Taras, 33).

(2) "Sustainable procurement logistics is about a mature and clear view of logistics operations. Its achieving requires the ability to assess effectiveness" (Zenovii, 60).

(3) "We always strive to reduce logistics costs. Advancing sustainable procurement logistics is no exception. Therefore, managers must be able not only to analyse the main costs but also to suggest ways to optimise them" (Mariia, 34). 
In the second stage, we obtained the analysis results of the competencies frequency (Table 2).

We found that managers most often tend to use such competencies as (1) qualifications;
(2) the ability to evaluate the effectiveness of logistics operations; (3) the rational management of financial flows for the logistics operations realisation.

Table 2. XYZ analysis of the logistics managers' competencies

\begin{tabular}{|c|c|c|c|c|c|c|}
\hline \multirow{2}{*}{$\mathrm{N}$} & \multirow[t]{2}{*}{ Competencies } & \multicolumn{3}{|c|}{ Frequency } & \multicolumn{2}{|c|}{ Group } \\
\hline & & daily & monthly & quarterly & $\mathrm{ABC}$ & $\mathrm{XYZ}$ \\
\hline 1 & $\begin{array}{l}\text { High qualification (mastery in theory and practical } \\
\text { tools of logistics) }\end{array}$ & $\mathrm{v}$ & & & A & $\mathrm{X}$ \\
\hline 2 & $\begin{array}{l}\text { Understanding the specifics of the industry and } \\
\text { region }\end{array}$ & & & $\mathrm{v}$ & $\mathrm{C}$ & Z \\
\hline 3 & Understanding the characteristics of the enterprise & & & $\mathrm{v}$ & $\mathrm{C}$ & $\mathrm{Y}$ \\
\hline 4 & $\begin{array}{l}\text { The ability to analyse and forecast stocks and needs } \\
\text { in them }\end{array}$ & & $\mathrm{v}$ & & $\mathrm{B}$ & Y \\
\hline 5 & $\begin{array}{l}\text { The ability to react quickly to changes in the } \\
\text { market conditions }\end{array}$ & & $\mathrm{v}$ & & B & Y \\
\hline 6 & The ability to establish business relationships & & $\mathrm{v}$ & & $\mathrm{B}$ & $\mathrm{Y}$ \\
\hline 7 & $\begin{array}{l}\text { The ability to analyse the structure of logistics costs } \\
\text { and optimise it }\end{array}$ & & $\mathrm{v}$ & & A & $\mathrm{Y}$ \\
\hline 8 & $\begin{array}{l}\text { The ability to assess the effectiveness of logistics } \\
\text { operations and processes objectively }\end{array}$ & $\mathrm{v}$ & & & A & X \\
\hline 9 & $\begin{array}{l}\text { The ability to develop, improve, and implement } \\
\text { new systems to optimise the logistics department's } \\
\text { work; }\end{array}$ & & & $\mathrm{v}$ & B & Z \\
\hline 10 & $\begin{array}{l}\text { The ability to generate reports on logistics costs (in } \\
\text { terms of month, quarter, year) }\end{array}$ & & & $\mathrm{v}$ & B & Z \\
\hline 11 & $\begin{array}{l}\text { The ability to coordinate document flow of } \\
\text { logistics processes }\end{array}$ & & $\mathrm{v}$ & & C & $\mathrm{Y}$ \\
\hline 12 & $\begin{array}{l}\text { The rational management of financial flows for the } \\
\text { logistics operations realisation }\end{array}$ & $\mathrm{V}$ & & & B & X \\
\hline
\end{tabular}

Source: Own research

The third competence fell into group "B" according to the $A B C$ analysis. Here is a typical statement of the manager, which acharacterises this competence:

"Advancing sustainable procurement logistics requires specific knowledge, skills and abilities. However, we try to find the best ways to direct financial flows to perform our daily tasks. It is about rationality in the work of the logistics manager" (Dmytro, 54).

Based on the results, we formed an integrated ABC-XYZ matrix (Figure 1).

Source: Own research

\begin{tabular}{|c|c|c|c|}
\hline & $\mathrm{X}$ & $\mathrm{Y}$ & $\mathrm{Z}$ \\
\hline $\mathrm{A}$ & 1,8 & 7 & - \\
\hline $\mathrm{B}$ & 12 & $4,5,6$ & 9,10 \\
\hline $\mathrm{C}$ & - & 3,11 & 2 \\
\hline
\end{tabular}

Figure 1. Integrated matrix of ABC-XYZ analysis results 


\section{DISCUSSION}

The competencies presented in the integrated matrix have significant potential in developing motivational policies of agricultural enterprises. The proposed approach helps implement the robust relationship between the critical competencies of the logistics manager, performance and motivation.

The question of ways to improve the management system of Ukrainian agricultural enterprises using logistics tools is highly relevant. A high-quality KPI system with a motivational component allows considering the specifics of the goals, objectives, operating conditions of agricultural enterprises to achieve sustainable development.

The functioning of agricultural enterprises against the background of the unstable economic situation in Ukraine and limited resources significantly narrow the possible framework of motivational policy. Identified key competencies can serve as a guide in this situation. The use of different combinations of motivational tools based on the competencies identified in this paper is essential. Such tools allow agricultural enterprises to develop, increase their capacity, and maintain a leading position in the country's agricultural market and abroad. In this light, the construction of the KPI-based motivation policy considers the requirements of the competence approach to developing competitive advantages of agricultural enterprises.

Implementation of motivation policy based on KPI and competence approach can be helpful to achieve sustainability of procurement logistics and has the following advantages:

- enrichment of motivational tools and increasing employee engagement;

- involvement and retention of professional specialists interested in the sustainability of procurement logistics;

- translation of priorities and tasks of the enterprise;

- optimal use of the payroll;

- increasing the effectiveness of monitoring the implementation of sustainable development goals;

The proposed approach helps spread knowledge about the relationship of personal responsibilities of the enterprise's logistics managers and strategic goals.

\section{This study has the following limitations.}

Geographical. This study uses data obtained by interviewing managers of Ukrainian agricultural enterprises. In a re-survey based on data from other countries, the results may be different due to economic, social and cultural variations.

Practical. The main disadvantage of KPI is that the interpretation of the results may not always be correct. This problem can be avoided by approving the evaluation strategy and objective evaluation rules when developing a KPI-based motivation policy.

\section{CONCLUSION}

In this study, we found how to form a KPI-based motivation policy of agricultural enterprises from the competency approach standpoint. During the theoretical study, we found that procurement logistics is the area in which the agricultural enterprise can achieve sustainable development. We substantiated the feasibility of constructing a motivational policy based on KPI and identified a missing element: the competence of logistics managers. During the empirical study using the method of integrated $\mathrm{ABC}-\mathrm{XYZ}$ analysis, we processed interviews with managers of logistics of agricultural enterprises. We found that the most critical competencies are high qualification and the ability to assess the effectiveness of logistics operations and processes objectively (group AX). We insist that interweaving tasks for the development and use of these competencies (as well as competencies were belonging to the AY, BX, BY groups, if resources allow) will ensure the development of the agricultural enterprise and achieving sustainable procurement logistics.

\section{References}

1. Abbasi, M., \& Nilsson, F. (2016). Developing environmentally sustainable logistics. Transportation Research Part D: Transport and Environment, 46, 273-283. https://doi.org/10.1016/j.trd.2016.04.004

2. Anokhina, M. Y., Abdrakhmanov, R., Gridneva, Y. E., Arrieta-López, M., Dzhalilova, N. R., \& Meza-Godoy, A. (2020). Formation of the competitive potential of the agricultural territories. Entrepreneurship and Sustainability Issues, 7(3), 
1921-1936.

https://doi.org/10.9770/jesi.2020.7.3(32)

3. Bahua, M.I. (2018). Managerial Competencies in Agriculture. EUROPEAN RESEARCH STUDIES JOURNAL, XXI (Issue 2), 623-629. https://doi.org/10.35808/ersj/1028

4. Björklund, M., \& Forslund, H. (2018). Exploring the sustainable logistics innovation process. Industrial Management \& Data Systems, 118(1), 204-217. https://doi.org/10.1108/IMDS02-2017-0058

5. Bulinski, J., Waszkiewicz, C., \& Buraczewski, P. (2013). Utilization of ABC/XYZ analysis in stock planning in the enterprise. Annals of Warsaw University of Life Sciences - SGGW, Agriculture, 89-96.

6. Cavalett, O., Chagas, M. F., Magalhães, P. S. G., Carvalho, J. L. N., Cardoso, T. F., Franco, H. C. J., Braunbeck, O. A., \& Bonomi, A. (2016). The Agricultural Production Model. B A. Bonomi, O. Cavalett, M. Pereira da Cunha, \& M. A. P. Lima (РеA.), Virtual Biorefinery (c. 13-51). Springer International Publishing. https://doi.org/10.1007/978-3-319-26045-7_3

7. Ciglovska, B. (2018). Developing Sustainable Agricultural Sector, as an Impetus for Macedonia`s Economic Growth. European Journal of Sustainable Development, 7(4). https://doi.org/10.14207/ejsd.2018.v7n4p545

8. Dankevych, E., Dankevych, V., \& Chaikin, O. (2017). Ukraine Agricultural Land Market Formation Preconditions. Acta Universitatis Agriculturae et Silviculturae Mendelianae Brunensis, 65(1), 259-271. https://doi.org/10.11118/actaun201765010259

9. Dar, W. D., \& Laxmipathi Gowda, C. L. (2013). Declining Agricultural Productivity and Global Food Security. Journal of Crop Improvement, 27(2), 242-254. https://doi.org/10.1080/15427528.2011.653097

10. Davis, P., Milne, B., Parker, K., Hider, P., Lay-Yee, R., Cumming, J., \& Graham, P. (2013). Efficiency, effectiveness, equity (E3). Evaluating hospital performance in three dimensions. Health Policy, 112(1-2), 19-27. https://doi.org/10.1016/j.healthpol.2013.02.008

11. de Bruijn H., ten Heuvelhof E.F., \& in 't Veld R. (2010) Positioning the Process Approach. In: Process Management. Springer, Berlin, Heidelberg. https://doi.org/10.1007/978-3-64213941-3_2

12. Dubrovsky, V. (2004). Toward system principles: General system theory and the alternative approach. Systems Research and
Behavioral Science, 21(2), 109-122. https://doi.org/10.1002/sres.572

13. Gaspart, F. (2013). Agricultural Policies for Poverty Reduction. European Review of Agricultural Economics, 40(1), 215-216. https://doi.org/10.1093/erae/jbs042

14. Gayfullina, M. M., \& Nizamova, G. Z. (2020). Methodology for evaluating the effectiveness of procurement logistics of an oil refinery. Petroleum Engineering, 18(3), 129. https://doi.org/10.17122/ngdelo-2020-3-129-137

15. Grabara, J. K. (2013). Sustainable Logistics Management. Universitatii "Lucian Blaga."

16. Grabara, J., C. Dima, I., Kot, S., \& Kwiatkowska, J. (2011). Case on In-House Logistics Modeling and Simulation. Research Journal of Applied Sciences, 6(7), 416-420. https://doi.org/10.3923/rjasci.2011.416.420

17. Grabara, J., Cehlar, M., \& Dabylova, M. (2019). Human factor as an important element of success in the implementation of new management solutions. Polish Journal of Management Studies, 20(2), 225-235. https://doi.org/10.17512/pjms.2019.20.2.19

18. Guo, X., Chen, T., Chen, K., \& Tang, Y. (2020). Design and Implementation of KPI Evaluation System. In Z. Xu, R. M. Parizi, M. Hammoudeh, \& O. Loyola-González (Eds.), Cyber Security Intelligence and Analytics (Vol. 1147, pp. 218-223). Springer International Publishing. https://doi.org/10.1007/978-3-03043309-3_29

19. Hamann, P. M., Schiemann, F., Bellora, L., \& Guenther, T. W. (2013). Exploring the Dimensions of Organizational Performance: A Construct Validity Study. Organizational Research Methods, 16(1), 67-87. https://doi.org/10.1177/1094428112470007

20. Holman, D., Wicher, P., Lenort, R., Dolejšová, V., Staš, D., \& Giurgiu, I. (2018). Sustainable Logistics Management in the 21st Century Requires Wholeness Systems Thinking. Sustainability, $\quad 10, \quad 4392$. http://dx.doi.org/10.3390/su10124392

21. J. Hall, D., R. Huscroft, J., T. Hazen, B., \& B. Hanna, J. (2013). Reverse logistics goals, metrics, and challenges: Perspectives from industry. International Journal of Physical Distribution \& Logistics Management, 43(9), 768785. https://doi.org/10.1108/IJPDLM-02-20120052

22. Kaur, H., \& Singh, S. P. (2019). Sustainable procurement and logistics for disaster 
resilient supply chain. Annals of Operations Research, 283(1-2), 309-354. https://doi.org/10.1007/s10479-016-2374-2

23. Lynn, F. A. (2015). Managerial Best Practices to Promote Sustainable Supply Chain Management \& New Product Development. In Applications of Contemporary Management Approaches in Supply Chains. IntechOpen. https://doi.org/10.5772/59581

24. Milan, G., Hodon, R., Binasova, V., Dulina, L., \& Gaso, M. (2018). Design of simulation-emulation logistics system. MM Science Journal, 2018(03), 2498-2502. https://doi.org/10.17973/MMSJ.2018_10_20187 8

25. Morali, O., \& Searcy, C. (2013). A Review of Sustainable Supply Chain Management Practices in Canada. Journal of Business Ethics, 117. https://doi.org/10.1007/s10551-012-1539-4

26. Poluga, R. G. (2010). Quistissenz des Supply Chain Managements: Was sie wirklich über Ihre Prozesse in Beschaffung, Fertigung, Lagerung und Logistik wissen müssen. SpringerVerlag Berlin Heidelberg. https://doi.org/10.1007/978-3-642-01584-7

27. Rozhdestvenskaya, E. M. (2017). Methodological Basis of KPI Motivation. 830837.

https:/ /doi.org/10.15405/epsbs.2017.07.02.107

28. Sandberg, E., \& Abrahamsson, M. (2011). Logistics capabilities for sustainable competitive advantage. International Journal of Logistics Research and Applications, 14(1), 61-75. https://doi.org/10.1080/13675567.2010.551110

29. Sergeeva, T. L. (2019). Development Of The KPI System Of Logistic Activity Of Agricultural Enterprise. 456-463. https://doi.org/10.15405/epsbs.2019.04.49

30. Somov, D. (2018). The functional approach to strategic management. Economic Annals-XXI, 171(5-6), 19-22. https://doi.org/10.21003/ea.V171-03

31. Soysal, M., \& Bloemhof-Ruwaard, J. M. (2017). Toward Sustainable Logistics. In D. Cinar,
K. Gakis, \& P. M. Pardalos (Eds.), Sustainable Logistics and Transportation (Vol. 129, pp. 1-17). Springer International Publishing. https://doi.org/10.1007/978-3-319-69215-9_1

32. Triki, C., \& Crainic, T. G. (2018). Special issue on: "Models and methods for the supply chain and logistics management". EURO Journal on Transportation and Logistics, 7(4), 311-313. https://doi.org/10.1007/s13676-0180137-8

33. Volkonskaya, A., Pashkina, O., Galenko, N., Kurlikov, O., \& Parsova, V. (2020). Electronic form of procurement in agricultural enterprises. BIO Web of Conferences, 17, 00127. https://doi.org/10.1051/bioconf/20201700127

34. Wang, Y., \& Hao, Y. (2013). KPI-Based Private Enterprise Staff Performance Index Design. In E. Qi, J. Shen, \& R. Dou (Eds.), The 19th International Conference on Industrial Engineering and Engineering Management (pp. 893-901). Springer Berlin Heidelberg. https://doi.org/10.1007/978-3-642-38427-1_94

35. Wannenwetsch, H. (2007). Integrierte Materialwirtschaft und Logistik: Beschaffung, Logistik, Materialwirtschaft und Produktion. Springer. https://doi.org/10.1007/10.1007/9783-540-29757-4

36. Wannes, A., \& Ghannouchi, S. A. (2019). KPI-Based Approach for Business Process Improvement. Procedia Computer Science, 164, 265-270.

https://doi.org/10.1016/j.procs.2019.12.182

37. Wichaisri, S., \& Sopadang, A. (2013). Sustainable logistics system: A framework and case study. 2013 IEEE International Conference on Industrial Engineering and Engineering Management, 1017-1021. https://doi.org/10.1109/IEEM.2013.6962564

38. Xuemei, F., \& Shujun, Z. (2016). Performance Evaluation for the Sustainable Supply Chain Management. In Sustainable Supply Chain Management. IntechOpen. https://doi.org/10.5772/63065 